\title{
AN EXPLORATION OF THE IMPACT OF HOTEL FACILITIES ON EMPLOYEE MOTIVATION AND PERFORMANCE: AN INDONESIA CASE STUDY
}

\author{
Nadhira Sukmana Putri ${ }^{1}$ \\ ${ }^{1}$ International Management Institute, Switzerland \\ ${ }^{*}$ Corresponding Author's e-mail: 310317@imi-Iuzern.com
}

\begin{abstract}
The purpose of this study is to examine the impact of staff facilities on employee motivation and performance by using a case-study of Oberoi Beach Resort - a five-star hotel situated in Lombok, Indonesia. This study begins with a review of the research background, aim, and objectives. The author then addressed issues in the hospitality industry and the importance of maintaining employee morale and productivity. Next, the main topics of this study, i.e. employee productivity \& well-being, staff facilities, motivation, and performance were analyzed. Such topics were narrowed and established as the basis for primary research. Mixed-method approach was adopted to verify theories with acquired data. Despite several limitations, this research found that wages, events for staff, and medical-room are effective in motivating them to perform better and to stay with the brand. Additionally, training and development is the best tool for performance enhancement.
\end{abstract}

Keywords: facilities; motivation; performance, employee; five-star hotel

\section{INTRODUCTION}

Since the 20th century, numerous nations have witnessed lifestyle improvements within the society, particularly improvements in the field of economy which increase people's standards of living and working. Hattingh (2017) states, during the last 20 years, a large number of organizations have evolved to modernize their workplace. Accordingly, nowadays we can see modern staff facilities in modern workplace. These consist of tangible and intangible staff facilities (Saif \& Siddiqui, 2019). Tangible staff facilities include training and development room, lounge, business-center, toilet \& shower room, lockers, canteen, and 
health unit room, whereas intangible staff facilities may include counselling, foreign language classes, and periodic staff events. Certain hotel companies provide those facilities to help employees enjoy lower levels of stress and create a comfortable workplace ambience merely for improving their productivity (Teja \& Oktavio, 2019). So, employees are able to perform their best when providing service to guest.

To produce the best product and service outcomes, hotel companies may prescribe discretion, such as, having a policy on providing staff facilities. As Shabrina \& Chair (2020) argues, adding staff facilities to a hotel property may improve employees' working performance and service quality. Similarly, Jayasinghe (2017) state that offering employee facilities represents an investment that helps hotels achieve their goals.

The employee performance is, of course, a significant factor not only in creating effective organizations, but also in achieving the short- and long-term organizational objectives (Rodriguez \& Walters, 2017). According to Herzberg (1959), there are two fundamental factors that can be used to help improve employee performance: extrinsic factors, which refer to the essential needs of employees, such as working conditions (including staff facilities), salary, and co-worker relations; and intrinsic factors, which refer to less tangible needs of employees, such as personal growth, achievement, and recognition.

McCoy \& Evans (2005) defines working conditions as a situation in which employees work in accordance with such things, e.g. amenities, facilities, physical environment, and stress. Following Rodriguez \& Walters (2017), staff facilities and salary have the highest impact in terms of improving employee motivation. Generally speaking, when employees do their job, they will feel empowered if they are surrounded by good working atmosphere and adequate staff facilities (Ongori, 2009). Some organizations believe, providing staff facilities would make employee more productive and be able to work as expected. Employee productivity is influenced by general working conditions for instance adequate facilities, working hours, and general working environment.

Organizations should also be concerned about paying salaries and service charges with appropriate amount since it could be appealing to enhance employee motivation and 
performance (Aguinis et al., 2013). Eventually, the provision of solid benefits for employees will allow organizations to attract, retain their employees and gain competitive advantage (Hussain et al., 2014).

The hospitality industry is growing rapidly and getting more competitive day by day. If hotel organizations are not able to pay attention to their employees, for example, by providing employee with staff facilities, serious problems might emerge; e.g. declining of revenue, productivity, quality of service, or even certain employee moves to competitor companies. Letting this happening for a long time may lead a company facing tight competition or even bankruptcy (Abeysekera, 2006). Therefore, organizations should look after their employees since employees will take care of the customer (Subramanian, 2018).

To be able to survive and compete, organizations must know how to improve the quality of their products and services. Obviously, this involves a consideration of human resources. Essentially, hotels employ human as intermediaries for achieving the organization's target (Oktavio \& Kaihatu, 2020). Earlier research has been conducted by Cintia \& Gilang (2016) to investigate the effect of compensation and tangible working conditions on employee performance and discipline. As a result, compensation and working conditions have a significant impact on improving performance and discipline of employee. However, Cintia \& Gilang (2016) assumes that there is another aspect that might also impact employee performance, for instance, organizational culture, leadership, and motivation.

Furthermore, according to Stavrinoudis \& Simos (2016), these are the challenges in carrying out research involving employees: in some hotel organizations, the human resource department has intense working hours and several employees are quiet reserved. They also strongly recommend analyzing CEO's views on empowerment and then comparing the result with the perceptions of employee as it may lead to contradictions, and ultimately, will create interesting conclusion (Kaihatu \& Oktavio, 2020).

Nonetheless, there is still limited specific study on how staff facilities could improve employee performance and motivation, particularly in hotel. This study will therefore focus on the impact of the provision of staff facilities (tangible and intangible) on employee performance 
and motivation. This study would be useful for hospitality sector particularly. Organizations may use this study as their guidance to strengthen their employee empowerment. On the other hand, having satisfied employees (with advantages they can get in the company) does not necessarily guarantee that a hotel will have good employee performance and happy costumers (Ford et al., 2005). A research has been conducted by linking more than 300 studies, and it shows that employee satisfaction affects performance less than 10 percent (Judge \& Locke, 1993). Occasionally, although some employees do not perform very well, they love their job. Some others might have more efforts to provide the guest with excellent service in spite of their dissatisfaction. Employee ability and role perception have a greater impact on performance enhancement. Customer satisfaction does not solely depend on employee satisfaction (Ford et al., 2005). From the discussion above, the question may be raised: does the provision of staff facilities actually has a significant impact on improving employee performance?

Against this background, the aim of this study is to explore the impact of staff facilities on employee performance, using a case study of a five-star hotel in Lombok, Indonesia. Particularly, the study focuses on the case of the Oberoi Hotel.

\section{METHODS}

This study used mixed-method approach which is incorporates qualitative and quantitative data collection techniques and processes (Saunders et al., 2016). Mixed-method research allows author to produce richer data and to point out the inconsistencies between qualitative and quantitative research outcomes. Accordingly, the author considers that mixedmethod is an ideal approach because it can assure that the derived statements from hotel superior and employees are truly synchronous regarding to the staff facilities effect. Furthermore, mixed methods will enable author to triangulate the information, leading in stronger and more accurate data outcomes (Dang, 2015). To triangulate the data, author will use surveys and interviews as the research instrument. Both will be incorporated to achieve 
the objective of this study, which conducts primary research to investigate the impact of hotel staff facilities on employee motivation and performance.

The research population of this study is all employees of Oberoi Hotel who have been working with the organization for at least one year. The author selected them as research participants because they are considered more suitable than other individuals. Employees who have been working for at least one year have experience of using the staff facilities, so they are knowledgeable about the investigated topic. An employee with higher position from the investigated hotel was also interviewed to provide the researcher with further and more detailed insights. The author will thus receive qualitative and detailed information.

Two research instruments are used to assist the author in achieving the research objectives of this study. A set of questions assigned in specific order or measurements is called a questionnaire (Goyder \& de Vaus, 1987). The questionnaires used within this study aim to explore whether or not employee facilities in Oberoi Hotel could enhance employee motivation and performance. To form the questions, the author highlighted key statements and topics inside on the basis of the literature review. The author developed 18 questions and divided the questionnaire into two parts. The first part of the questionnaire consists of respondent's personal data (without mentioning name), whereas the second part comprises questions designed to compare intangible and tangible employee facilities and determine which of them has more influence on employee motivation and performance. Most of the questions are close-ended and there is a 'not applicable' option just in case the examined hotel does not provide certain employee facilities. Ultimately, the author included one openended question respondents to have a free space to share information freely. The author expects respondents to supply any answer regarding additional staff facilities that respondents expect from the hotel organization by using their own 'voices'. This study also uses research interview. The function of this interaction is asking relevant parties with assigned questions by author (Saunders et al., 2016). The questions, nevertheless, should be straightforward and understandable. The main purpose of this instrument is to provide the author with ideas related to the research objectives. 
More specifically, the author drew questions from the questionnaire as a basis for developing the interview schedule, yet presented them in open-ended format (without any scales). However, the interview was undertaken with human resources manager to explore his perspectives from the managerial standpoint regarding the provision of staff facilities. Do they find those staff facilities literally affect the employee motivation and performance? Essentially, the author wants to compare acquired responses from both employees and superiors. Additional questions may arise during the interview to answer research questions and objectives.

The author distributed the questionnaire through the online survey platform, Google Forms. Online survey is widely used nowadays to collect data since researcher could be more flexible in analyzing data, obtaining large samples, reaching sample globally (Evans \& Mathur, 2005). Oberoi Hotel employees were able to fill out this questionnaire online since January, 2020. The author contacted and asked the human resource director for permission in order to get in touch with the respondents. Then, author sent the survey link to the human resource manager, and he distributed it through an internal staff group.

As already mentioned, the author used interview to obtain qualitative data. The interview session was led by the author, starting with introduction, informing the confidentiality of this conversation (as a way of conducting ethical management), and questions \& answer session. The human resources manager was interviewed over the telephone, and the conversation was recorded (with permission of the interviewee). Despite the fact that telephone interviewing is cost- and time-effective, it was challenging for author to create a connection with the interviewee. Author was unable to observe the interviewee's face expressions and gestures when answering the questions. Essentially, it was difficult to determine whether or not the interviewee was truthful.

Since the object and subjects of this study are all in Indonesia, the author made the instruments into two languages - English and Indonesian. The pilot study was carried out with 10 Indonesian on December, 2019 to make sure all points are easy to understand from native people's perceptions. All 10 participants were students from different universities in Indonesia 
working in hotels. As a result of this pilot study, questions number one and four were revised by author.

\section{RESULT AND DISCUSSION}

Table 1 delineates the survey demographics, and it is divided into five-different variables. It could be seen from the table that in terms of gender, the highest percentage of respondents were female (62.1\%), and the youngest age group was $21-30$ years old $(57.5 \%)$. Employees working in Food \& Beverage Department were the majority of respondents, followed by employees in Front Office and Housekeeping Departments respectively. With respect to their education level, most respondents held a Diploma/Bachelor Degree $(60.6 \%)$, while $37.8 \%$ had vocational qualifications. More than two thirds of research participants had worked at the hotel more than three years.

Table 1. Survey Demographics

\begin{tabular}{|c|c|c|c|c|c|}
\hline Variables & $\begin{array}{c}\text { Number } \\
(n=66)\end{array}$ & Percentage & Variables & $\begin{array}{c}\text { Number } \\
(n=66)\end{array}$ & Percentage \\
\hline \multicolumn{3}{|l|}{ Gender } & \multicolumn{3}{|l|}{ Working Departments } \\
\hline Female & 41 & $62,1 \%$ & Front Office & 13 & $19,6 \%$ \\
\hline Male & 25 & $37,8 \%$ & Food \& Beverage & 14 & $21,2 \%$ \\
\hline \multicolumn{3}{|l|}{ Age (years old) } & Kitchen & 6 & $9,0 \%$ \\
\hline $21-30$ & 38 & $57,5 \%$ & Housekeeping & 11 & $16,6 \%$ \\
\hline $31-40$ & 20 & $30,3 \%$ & Sales \& Marketing & 7 & 10,6 \\
\hline $41-50$ & 8 & $12,1 \%$ & Purchase \& Store & 3 & $4,5 \%$ \\
\hline $51-60$ & & & Engineering & 3 & $4,5 \%$ \\
\hline \multicolumn{3}{|c|}{ Last Education Level } & Security & 2 & $3,0 \%$ \\
\hline Vocational & 25 & $37,8 \%$ & Health SPA & 2 & $3,0 \%$ \\
\hline Diploma/Bachelor & 40 & $60,6 \%$ & Accounting & 2 & $3,0 \%$ \\
\hline Masters & 1 & $1,51 \%$ & Human Resources & 1 & $1,5 \%$ \\
\hline \multicolumn{3}{|l|}{ Working Durations } & IT & 1 & $1,5 \%$ \\
\hline $1-2$ years & 22 & $33,3 \%$ & \multirow[t]{4}{*}{ Hygiene \& Food Safety } & \multirow[t]{4}{*}{1} & \multirow[t]{4}{*}{$1,5 \%$} \\
\hline $3-5$ years & 27 & $40,9 \%$ & & & \\
\hline $6-10$ years & 12 & $18,1 \%$ & & & \\
\hline$>10$ years & 5 & $7,5 \%$ & & & \\
\hline
\end{tabular}

As regards the interview, the author had the opportunity to gain deeper information from the human resource manager. At first, it was the intention of the author to involve two more managers, i.e. the food \& beverage and front office manager of Oberoi Hotel. Unfortunately, though these respondents have initially agreed to participate in the interviews, in due course 
they failed to participate as they were very busy for preparing Christmas and New Year's events. The author proposed alternative dates for conducting the interviews, but the managers declined all of them due to their dense schedule. This means that only one interview was conducted, which is acknowledged as a research limitation of this study. The interviewed human resources manager, Mr. Wahyu Dwiswarna, is a 42-years-old man. He has worked at Oberoi Hotel for 22 years. Mr. Wahyu Dwiswarna began his career in the food and beverage department as a waiter at the Oberoi and was later promoted to a senior food \& beverage assistant. Then, he was recently promoted to fill the position as human resource manager. Given his long working experience with the organization, both as an employee and manager, his views are considered most insightful with respect to the research objectives of this study. To some extent, perhaps this alleviates the non-participation of other interviewees.

\subsection{Employee Productivity and Well-being}

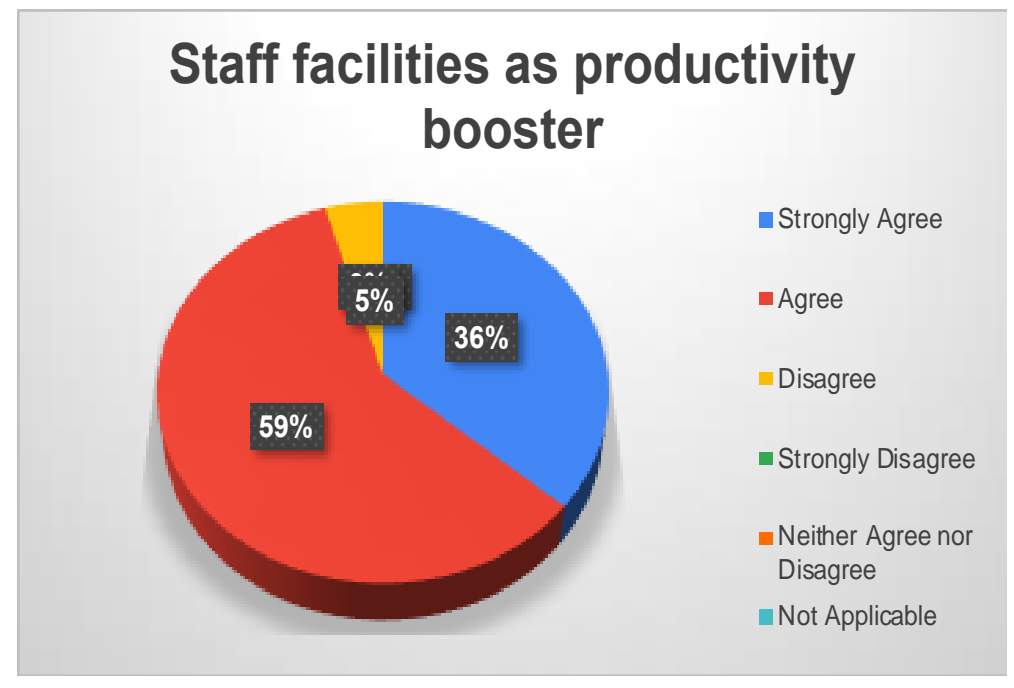

Figure 1. Staff Facilities Impact on Productivity

Study findings indicate that staff facilities are one of the factors driving employee productivity. The chart depicts that $59 \%$ of respondents agreed, and this essentially validated the statement of Parveen et al. (2015). Parveen et al. (2015) stated that if an organization pays attention to their employees, i.e. providing facilities, this could boost their productivity. 


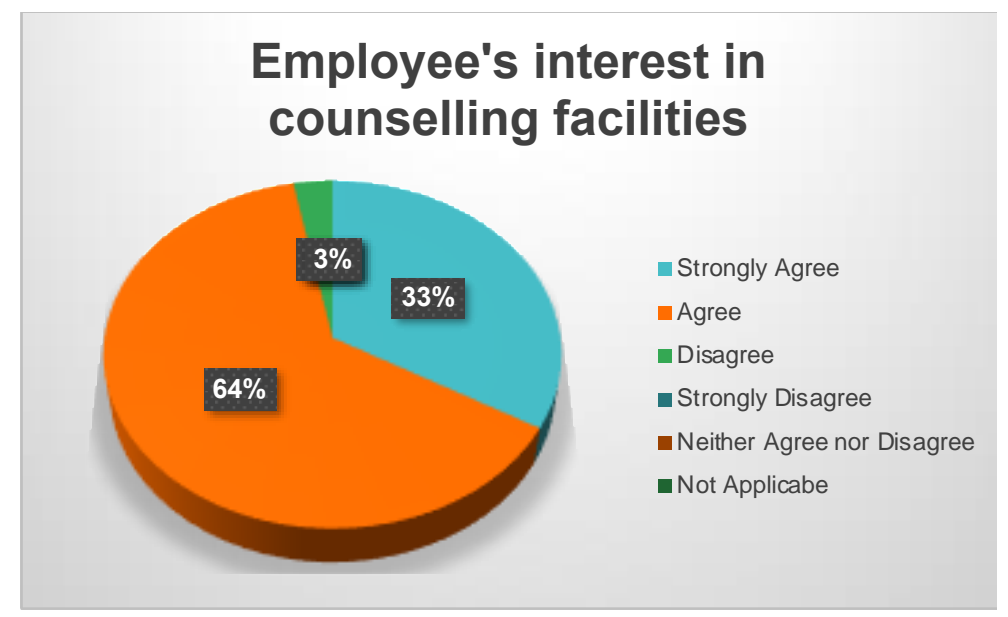

Figure 2. Employee's Interest in Counselling Facilities

Furthermore, employees of Oberoi have a high interest in counselling facilities. This finding is in line with (Jayasinghe, 2017) who argues that, giving attention to employee wellbeing is crucial as it directly affects productivity. Interestingly, the importance of facilities was also raised during the interview. In the words of the interviewee: "It is true that our employees are highly motivated to work if we provide and pay special attention to staff facilities, particularly with regard to salary and service charges. I assume the employees are happy and have such greater motivation to work during peak season (on July and August) because they can earn more money from service charge in addition to the basic salary." With respect to counselling services, he went on to add that: "None of the employees have ever asked me to provide counselling services within this property. However, we do have labour unions, and this is aimed at integrating and solving problems between hotel management and employees. So, when employees have problems with financing/working agreements, they usually speak up to through the union as mediator. Conversely, if they are seeking advice for something more personal, e.g. life issues, sex-harassment, usually employees directly come-in and talk to me privately in HR office." Generally speaking, then, staff facilities do affect positively employee's productivity, particularly basic wages and service charges. Both of them have the greatest potential to boost productivity. Then, so far the human resources department still has capacity 
to provide counselling service, so in Mr. Wahyu's view, it is not necessary needed to provide "a special dedicated" counselling services within Oberoi.

\subsection{Employee Facilities}

\subsubsection{Intangible}

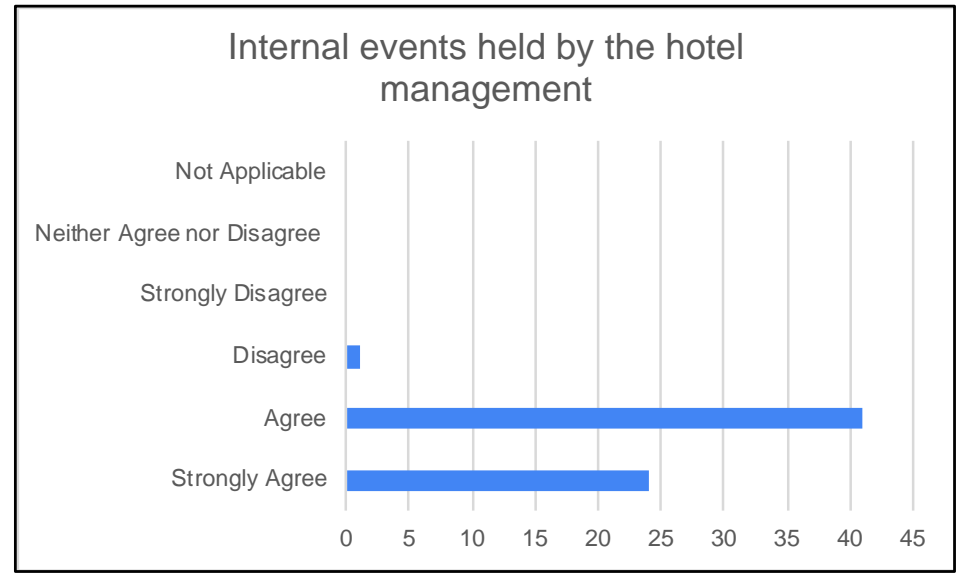

Figure 3. Internal Staff Events Held by Hotel Management

For intangible facilities, data obtained indicates that internal events almost unanimously acknowledged as facilitating and boosting employee morale and productivity (see Figure 3). Employee motivation and performance will improve if the hotel organization consistently facilitated the internal staff events (Maroudas et al., 2008; Oktavio et al., 2020). Staff feels that their dedication is being respected through such events, and they are encouraged to show higher work performance.

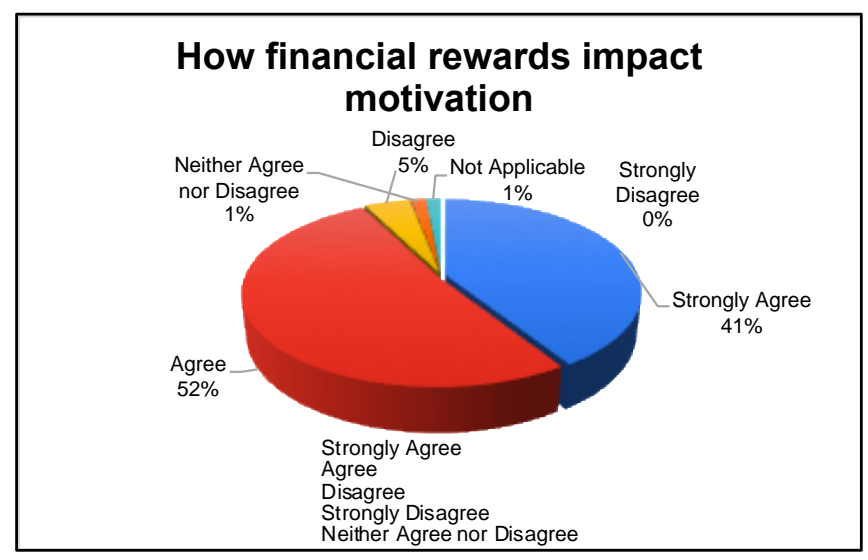

Figure 4. Financial Rewards Impact on Motivation 


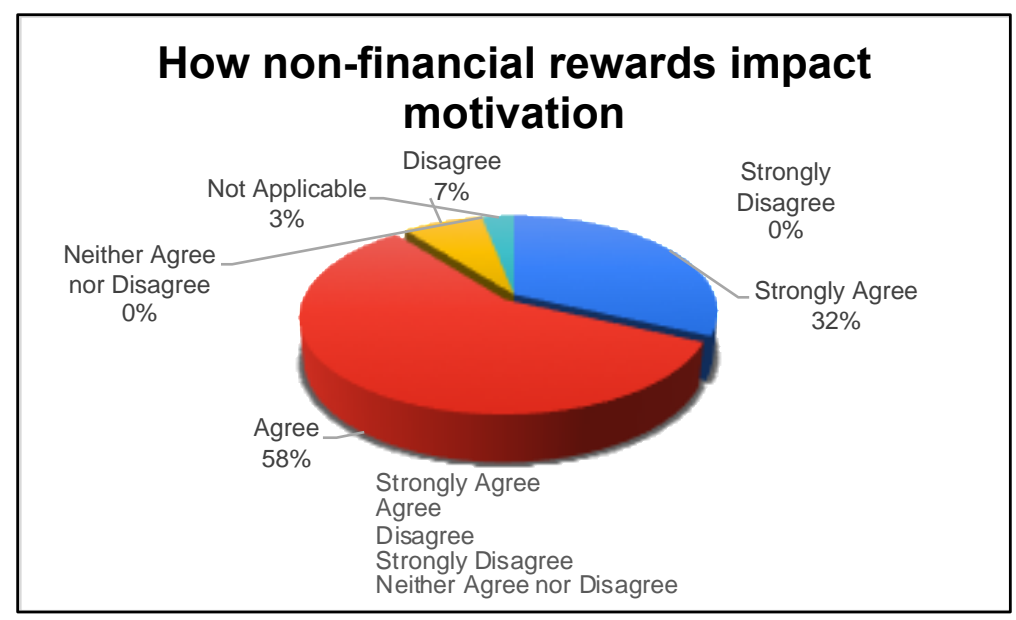

Figure 1. Non-financial Rewards Impact on Motivation

Interestingly, financial reward earned the lowest percentage (52\%) among three others intangible facilities. The author then compared between non-financial and financial rewards. This study finds that Oberoi's employees are more motivated by non-financial rewards as the percentage of non-financial rewards appeared to be higher (6\%) than financial rewards. These findings seem to contradict earlier reported findings on employee productivity and well-being. Contradictions in a mixed-method approach are not uncommon (Diloreto \& Gaines, 2016). The author suggests that further research on this subtopic needs to be undertaken so as to throw light on this contradiction.

Additionally, based on answers from open-ended questions, the author discovered that the demand for intangible facilities is high. Oberoi's employees asked the organization to facilitate them with following programs: beauty class, retirement scheme, financial training, sports \& music courses, and rewards in the form of travel tickets. In a similar vein, albeit in a more limited scope, Mr. Wahyu stated: "Our employees are very excited when it comes to internal events for staff. I presume that employees could burn, release their stress, and bonding with everybody including superiors, especially, the general manager. In 2018 and 2019, Oberoi did not celebrate the hotel's birthday due to a massive earthquake in Lombok, because we were in a 'recovery-mode'. And, we finally held an event again before Christmas, 
it was an "outing". Our employees always felt refreshed after an event. Also, they are very happy to have the chance to bond together with superiors with no boundaries. That is precious."

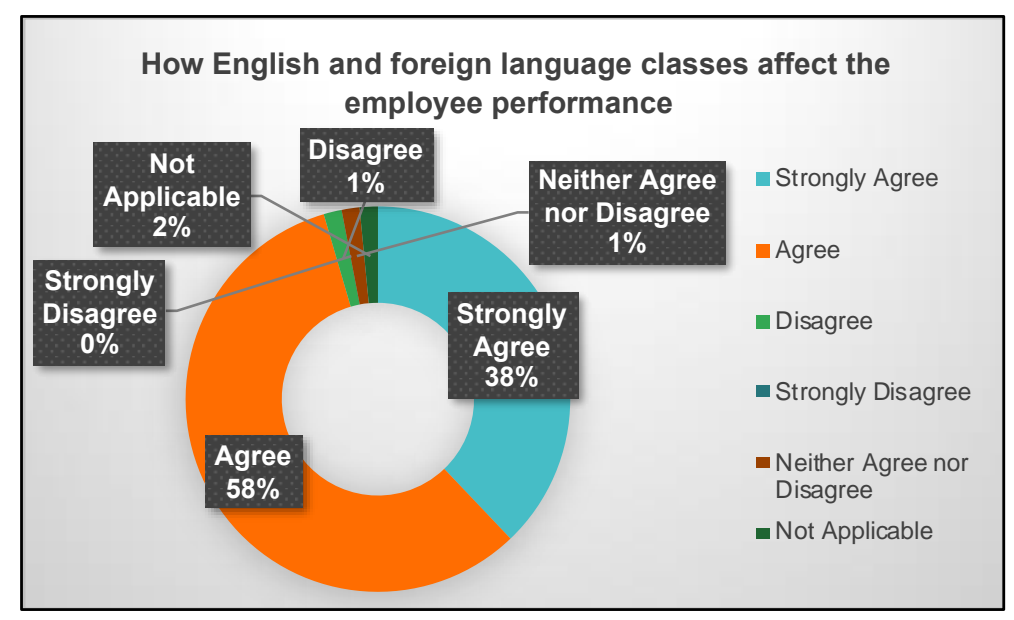

Figure 6. Classes in Foreign Languages Enhance Performance

Furthermore, this research has shown that language classes can also inspire employees to perform better. $96 \%$ of respondents agreed that language classes are very useful for communicating, assisting the guests, and handling complaints. Consequently, this finding clearly supports Ariffin's (2013) claims.

To emphasize the above information, the interviewee mentioned: "It is mandatory for all Oberoi employees to attend language classes. The classes last for three months, and it is conducted within the hotel. We collaborate with Indonesia Australia Language Foundation for supporting this staff facility. As I said, we realize that our employees are already busy, so the language classes here follow the "module system". It means that the program is lighter and completely for tourism purposes. We used to have classes in Korean, Japanese, and Russian back then, yet we stopped it because now we rarely host guests from those countries. The improvements are incredible. Majority of employees can communicate with confidence. I would like to highlight that the employees are able to communicate politer and professional." By making language classes mandatory, employees will be able to learn constantly, to master new language, and to be more confident while serving the hotel guests. 


\subsubsection{Tangible}

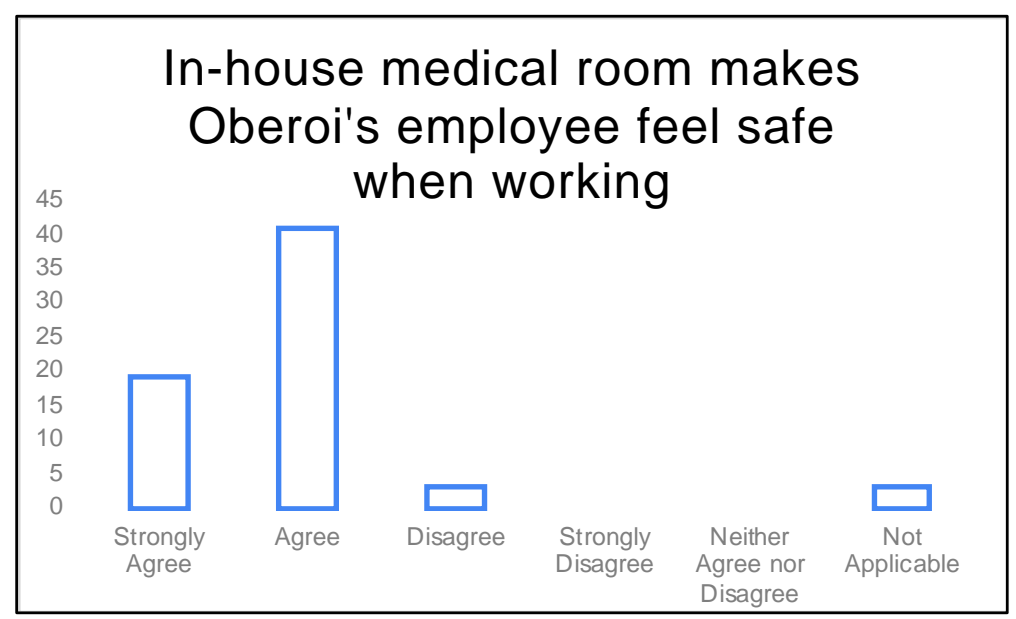

Figure 7. Medical-room Provides Employees a Sense of Safety

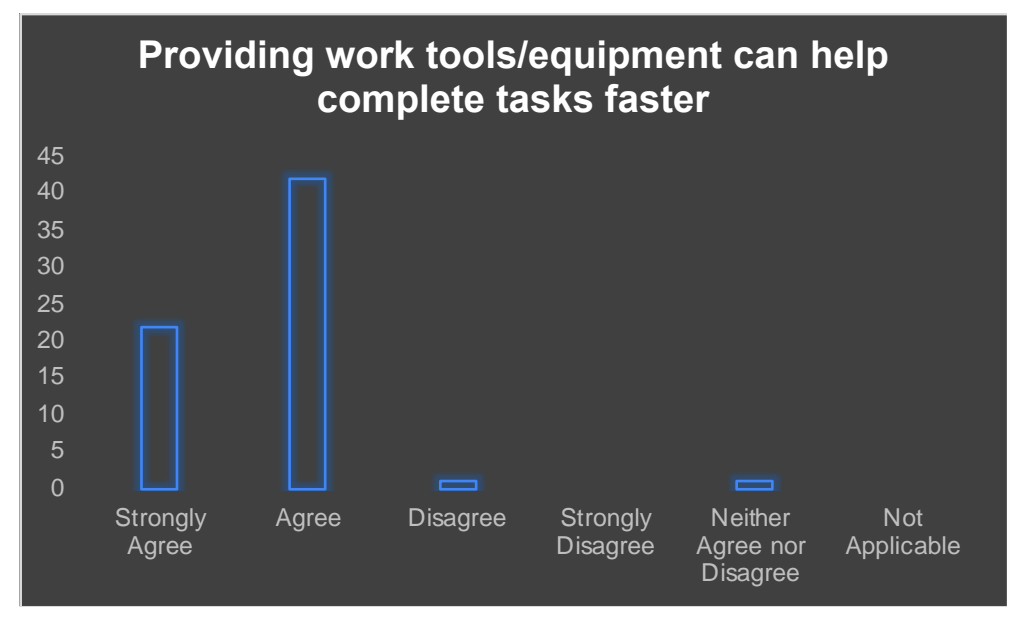

Figure 8. Tools/Equipment Enable Employees to Work Faster

Contrary, medical-room, which is part of social facilities, earned the highest agreement percentage $(63,6 \%)$. In this connection, employees agreed that they feel safer at work due to the existence of medical rooms within the hotel. The next result is that employees feel that they can fulfill their responsibilities more efficiently and in a timely manner because of the provision of working equipment facilities (computer, tablet, etc.). From the open-ended answers, some employees requested that Oberoi needs to revive the staff rest area with the "split-level" room concept. The split-level concept was invented in America. This concept links every floor with another floor, within the room. By installing this concept, the resting-area will 
be more spacious. Split-level idea allows the users to have more intense social interactions as each floor connects with another. Besides that, another respondent wished that their social facilities, e.g. lockers and canteen, can be refurbished.

On these issues, results from the interview suggested the following: "It is absolutely true that our employees feel secure because of the medical room existences. Indeed, medical room is the most used tangible facility. Oberoi invites medical doctor to visit once a week for two hours (it is available on call for 24 hours) and the nurse is always standby here every day at any time. Employees can come, do a medical-check, and ask for prescriptions. Besides that, Oberoi cooperates with a pharmacy and eye-optic. So, if our employees need medicine or glasses, they just need to take it, and Oberoi will pay for it. Oberoi does this for all employees, temporary and permanent, without minimum working duration."

In addition to the above, the interviewee stated: "Recently, the management has just stopped our split-room concept resting area due to some employees demonstrating bad behaviour. We used to provide a special space for them with computer, library, games, and a reading area. However, they were not responsible. For instance, they did not clear up the space after using it and some employees smoke inside the rest-area, whereas the area is equipped with air-conditioner. So for now, we operate this room only during special occasions, e.g. during Ramadan." For intangible facilities, then, internal events have a more significant impact on employee motivation and performance than language classes. Employees are able to bond with colleagues and relax for a while, and most of them find this as 'priceless feeling'. Whereas for tangible facilities, this study indicates that medical-room and resting-area are the most vital facilities for improving employee motivation and performance.

\subsection{Motivation}

In survey questions number 13 and 14 (about tangible and intangible facilities respectively), the author attempted to compare and probe, the exact type of facility that has a greater impact on employee motivation. 


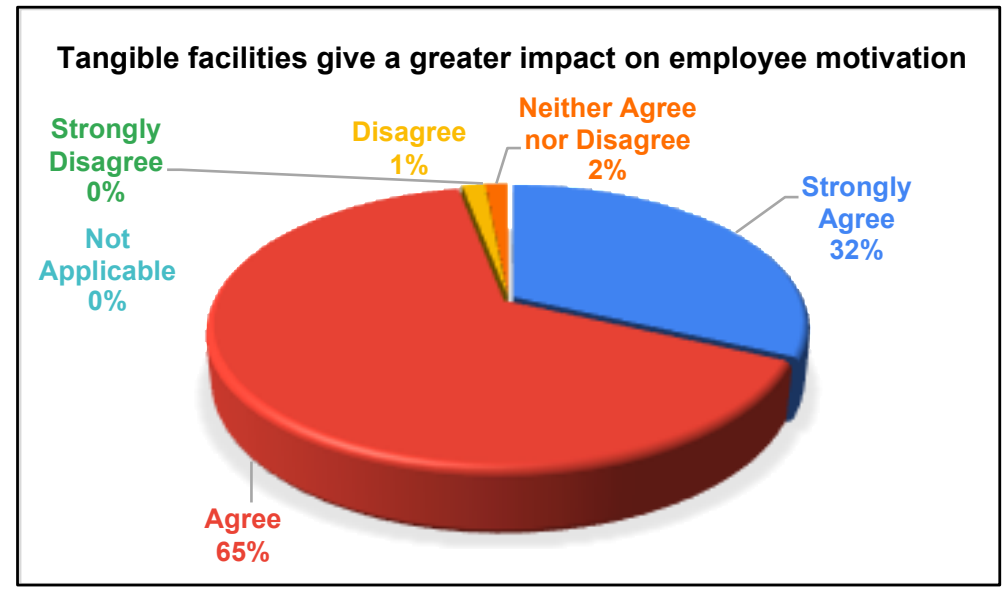

Figure 9. Relation between Tangible Facilities and Motivation

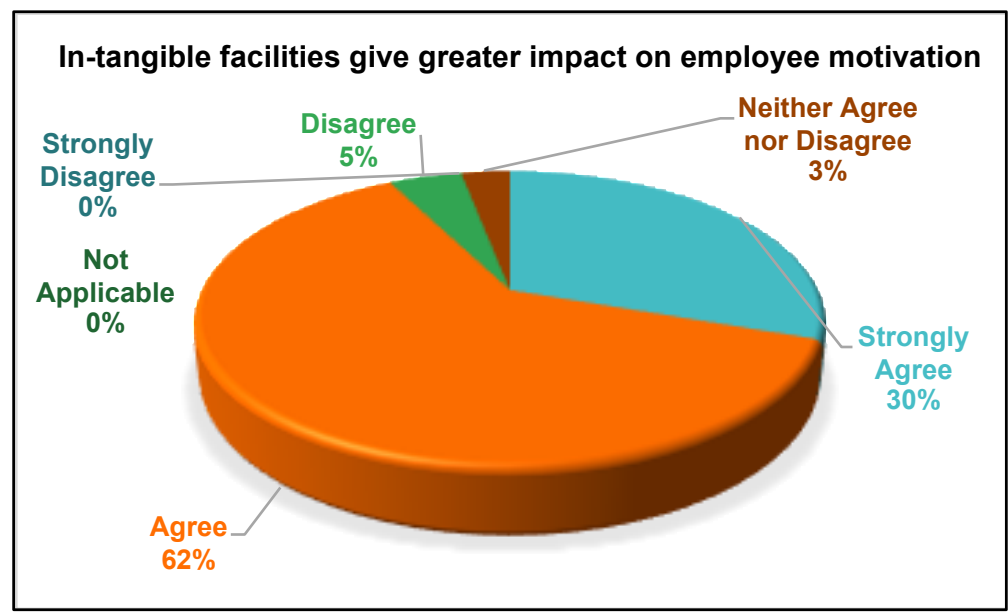

Figure 10. Relation between In-tangible Facilities and Motivation

Munawirsyah (2017) claimed that if an organization provides its employees with both types of facilities, the greater the motivation will be. Their argument was then confirmed in this study. This study reveals that tangible facilities have more significant impact in promoting employee motivation as the survey results indicate that question 13 has higher 'agree' $(3 \%)$ answer than questions number 14. So, this finding is relevant to Duque et al. (2020) that tangible facilities are becoming increasingly important and employees enjoy them more. Specifically, tangible facilities who can work optimally with nice design concept. 


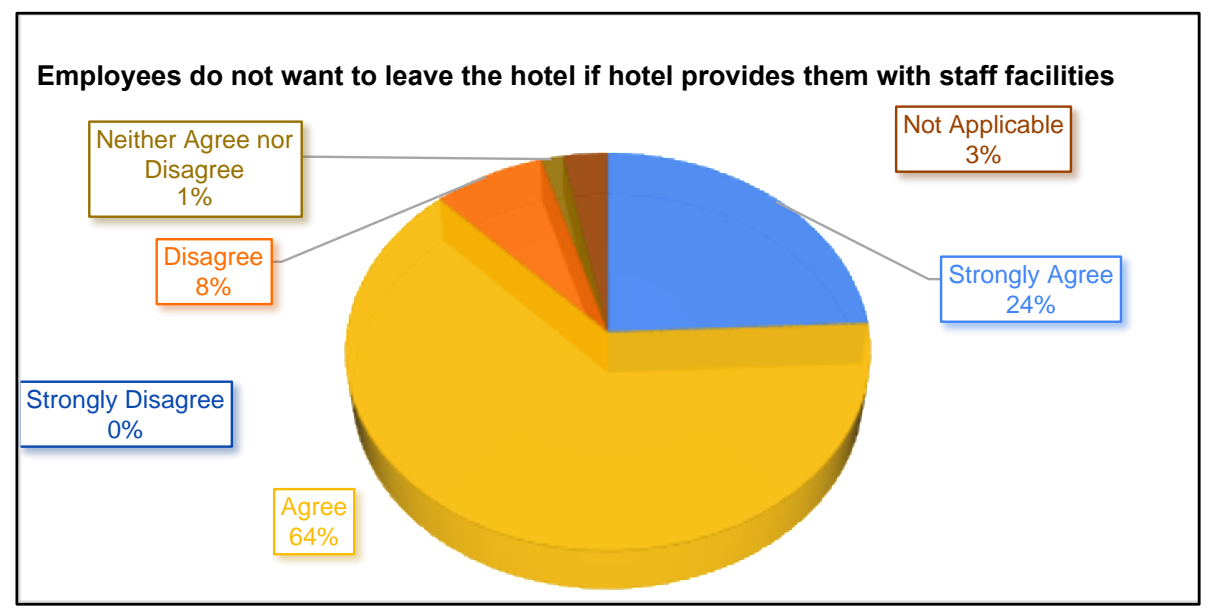

Figure 11. Employee's Reluctance to Leave the Brand due to Facilities Provision

Other than that, despite a small percentage of respondent disagreement $(8 \%)$, the vast majority of respondents (88\%) agreed or strongly agreed that their desire to leave the organization will diminish if the organization provides them with the necessary facilities, for they feel satisfied. This suggests that work facilities are an indicator of employee satisfaction. So, this finding is consistent with Parveen et al. (2015).

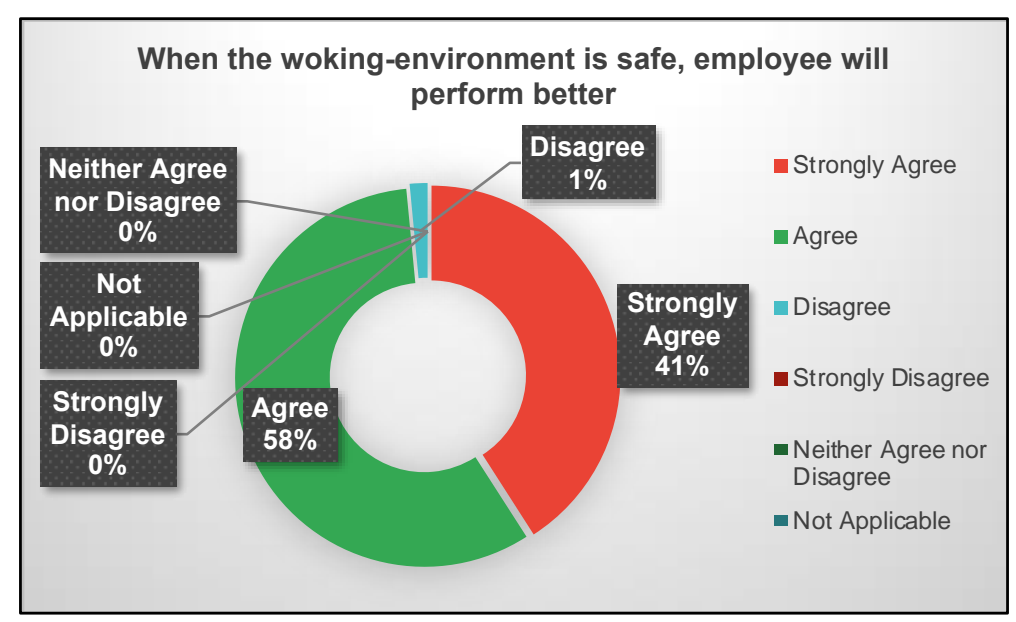

Figure 12. Safe Working-Environments Stimulate Higher Performance

Using an open-ended format, the author asked the type of facilities that can improve the motivation of Oberoi's employees. Seventeen out of 66 respondents answered basic salary increases. Furthermore, $57,6 \%$ of respondents agreed and $40,9 \%$ strongly agreed that if their work-environment is conducive and safe, they will be driven to perform better. This is 
consistent with Kok \& Muula (2013) statement about salary and work-environment. A relevant comment regarding tangible facilities was raised during the interview: "Tangible facilities, especially medical room, canteen and rest-area (social facilities) often make most employees feel comfortable and relaxed during break-time. Particularly employees feel comfortable because all services within the clinic are free." Overall, providing staff facilities seems to make most employees reluctant to leave the organization. Specifically, tangible facilities (medicalroom particularly) give greater influence to boost motivation. Equally important for their motivation level, several employees mentioned that wage increases and conducive working conditions matter.

\subsection{Performance}

Main human resource problem within the hotel industry is lack of hospitality knowledge and language skills. To investigate these issues, the author asked directly the employees whether training \& development and language classes have a significant effect on their performance.

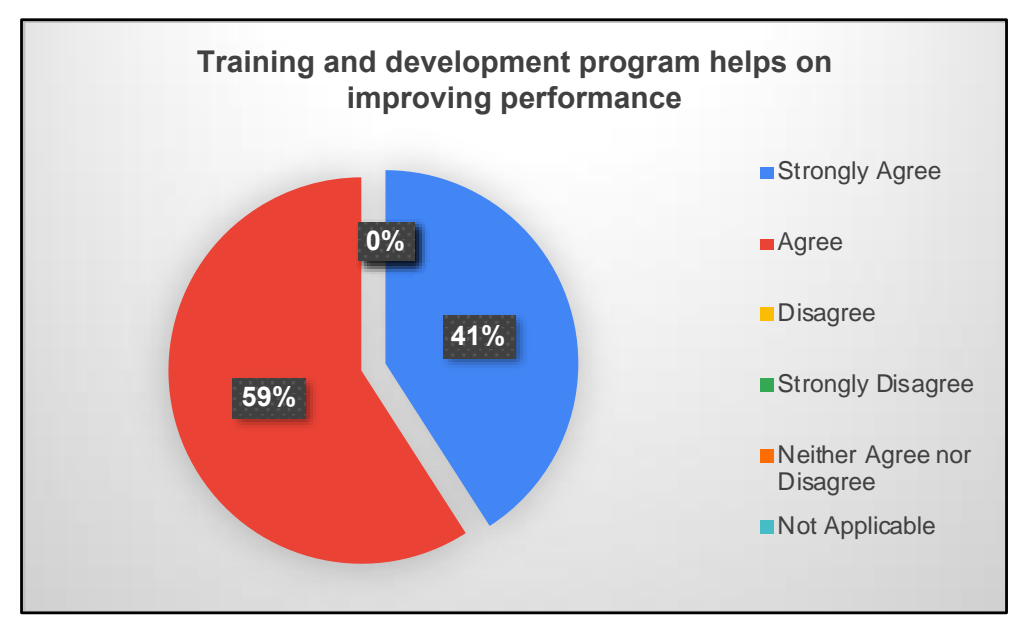

Figure 13. Training and Development Impact on Performance 


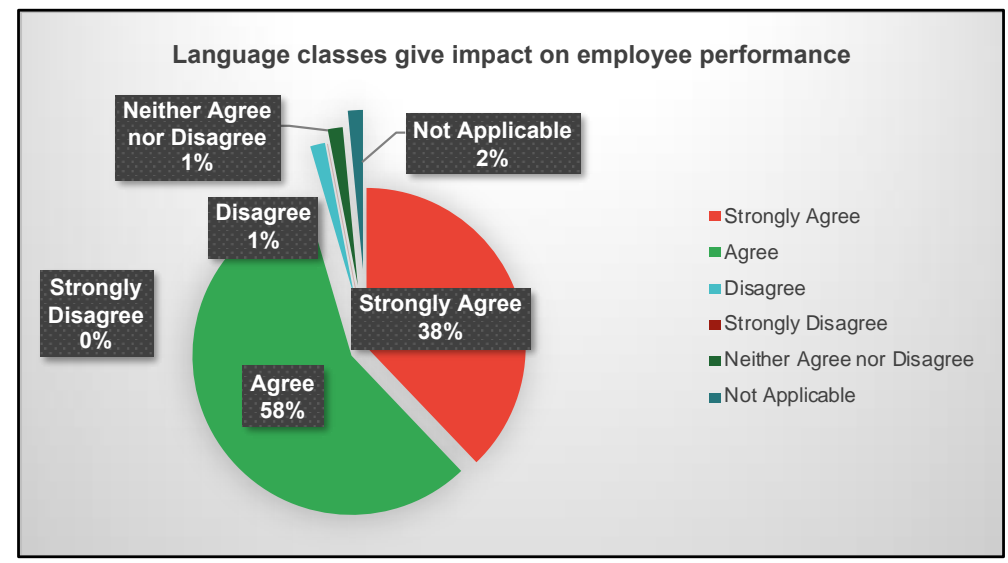

Figure 14. Relation between Language Classes and Performance

These findings are depicted in Figures 13 and Figure 14. In quantitative instrument, author obtained that all employees agreed that training and development have a significant impact on performance improvements. Also, for language classes, the majority of employees also agreed, despite $4,5 \%$ did not agree or, in other words they felt that language class does not contribute to their performance. This confirms Teja \& Oktavio (2019) that this hotel must put training \& development (hotel knowledge and languages) as primary concerns because of its immense contribution to improving employee performance. Concerning performance, Kartika et al. (2019) states that performance should be routinely assessed, and Oberoi has the tools to measure employee performance. In the interviewee's words: "Personally, as a human resource manager, I find that performance appraisal is not being used effectively within this department. Because most Indonesians, like me, often feel guilty (involving feeling too much) to give bad marks to the employee. So, it means that this measurement is still used subjectively not objectively in Oberoi Lombok. Nonetheless, performance appraisal is indeed useful for decisions-making, particularly as an indicator of salary increases." This statement validated all statements concerning performance. Starting with, Kartika et al. (2019) that performance appraisal can be used for quantifying good and bad performance and identifying poor performance and developmental areas (Mitrović et al., 2016). Performance appraisal furthermore is used as a basis for creating decisions, such as, policy making (Bretz et al., 
1992). Finally, human resource department may use the results for planning, for example, recruitment, selection process, promotion, and evaluation.

With respect to the above findings, this study shows that training and development is the most important facility for improving employee performance. Also, despite the fact that performance appraisal is sometimes used ineffectively, it still helps Oberoi to identify developmental areas, make policy, and create plans

\section{CONCLUSIONS}

This study achieved the first objective by exploring and assessing several topics: employee productivity \& well-being, staff facilities, motivation, and performance. Every subtopic comprises problems, indicators, and theories that are useful for the composition of quantitative (survey) and qualitative (semi-structured) instruments. Furthermore, the literature review allows author to either refute/confirm the research findings because secondary research findings are strongly linked to primary research outcomes. Therefore, first objective was completed successfully because the literature review analysis helped verify all main research findings. Second objective was accomplished by the author. The methodology provides evidence of the process followed. Despite several limitations, the primary research was conducted by adopting a mixed-method approach. Qualitative and quantitative methods were used, which allowed the author to obtain maximum research outcomes. Quantitative research aims to explore the level of staff facilities impact on their motivation and performance. The quantitative research was executed in form of survey which only can be filled by Oberoi's employees; meanwhile, semi-structured interview was implemented to complete the qualitative research. The aim of this method is exactly the same with the survey, but here, author wanted to gain deeper-insights and to confirm the quantitative results.

The results from primary research revealed that staff facilities (especially wages and service-charges) have the biggest effect on improving employee productivity and well-being. While for intangible and tangible facilities, this study found that (respectively) internal events for staff and medical-room are facilities that contribute a huge impact on employee motivation 
and performance. Then for subtopic motivation, the research findings have proven that providing staff facilities can encourage employees to perform better and to stay with the brand. Lastly, the best tool for enhancing employee performance is training and development.

As the first and second objectives have been met, the author is eligible to fulfill this goal. Recommendations are therefore presented, drawing on both primary and secondary research findings. Firstly, the results show that internal events for staff are the most influential intangible facilities. Therefore, the events must be held routinely by management. It will be better to add more types of events, so employees have plenty of chance to bond with their colleagues and to release stress. Secondly, several proposed programs can be added in the training \& development and rewards to make employees more competent and enthusiastic when working. For training \& development, Oberoi has to provide beauty-training for grooming purposes, as well as training for other departments - finance. Then, Oberoi may consider planning employee retirement programs. Author believes that this program will be groundbreaking since majority of Indonesian private companies rarely have retirement program. Giving travel tickets for rewarding employees also can be such a good alternative. Thirdly, medical-room is tangible facility with greatest impact on overall employee productivity. The function therefore needs to be improved. Perhaps by increasing the number of doctor visits, so more employees can use this facility. Lastly, the author strongly recommends that Human Resource Department remain professional and not involve feelings when evaluating employee performance with performance appraisal. Because this assessment has a crucial influence on hotel management decision-making. Hotel management already provides numerous facilities, particularly tangible. So, it is better to look after them. Because if it is not being cared, the management will withdraw those facilities. Additionally, it is best to always clearly communicate all problems related to staff and working facilities so that solutions can be made.

This study encountered a number of limitations that should be avoided by future researchers. First, this study was conducted in a particular organization, Oberoi Hotel. The number of research respondent was therefore limited, only for employees who work for Oberoi 
Hotel. 66 out of 110 employees working in this hotel participated in this study. Though this represents more than half of the hotel employees, it needs to be acknowledged that it represents a small number for the purposes of quantitative analysis. In any case, many employees did not manage to take part in the study because they were already busy and tired. This was the main limitation, because it obstructed certain aspects within this study. Next, the author had difficulty finding literature about "staff facilities" in the hospitality industry. So, whenever finding information about this topic, the author always got general information. This meant that the information mainly did not come from hospitality sources. This limitation occurred because there are still small number of people who are interested in raising this topic.

Future research may include a psychological approach in order to be able to accurately measure employee motivation and performance. It will be interesting to involve more than one hotel in future research. Particularly hotels located on different cultural contexts may produce different results, involving different cultures and habits. Extra work on methodological approaches (either qualitative, quantitative, or both) is required as it will help explore and determine exactly whether tangible or intangible facilities have the greatest impact on motivation and performance. Owing to time restrictions, the author strongly recommends that future researchers spend longer time for conducting the research. As they can do a thoroughexamination of the research object and samples.

\section{REFERENCES}

Abeysekera, I. (2006). Managing human capital in a privately owned public hotel chain. International Journal of Hospitality Management, 25(4), 586-601. https://doi.org/10.1016/j.ijhm.2005.04.006

Aguinis, H., Joo, H., \& Gottfredson, R. K. (2013). What monetary rewards can and cannot do: How to show employees the money. Business Horizons, 56(2), 241-249. https://doi.org/10.1016/j.bushor.2012.11.007

Ariffin, A. A. M. (2013). Generic dimensionality of hospitality in the hotel industry: A hostguest relationship perspective. International Journal of Hospitality Management, 35, 171-179. https://doi.org/10.1016/j.ijhm.2013.06.002

Bretz, R. D., Milkovich, G. T., \& Read, W. (1992). The current state of performance appraisal research and practice: Concerns, directions, and implications. Journal of Management, 18(2), 321-352. https://doi.org/10.1177/014920639201800206

Cintia, E., \& Gilang, A. (2016). Pengaruh lingkungan kerja fisik dan nonfisik terhadap kinerja karyawan pada KPPN Bandung I. Jurnal Sosioteknologi, 15(1), 136-154.

https://doi.org/10.5614/sostek.itbj.2016.15.1.12 
Dang, V. H. (2015). A mixed method approach enabling the triangulation technique: Case study in Vietnam. World Journal of Social Science, 2(2). https://doi.org/10.5430/wjss.v2n2p1

Diloreto, M., \& Gaines, T. (2016). An investigation of discrepancies between qualitative and quantitative findings in survey research. In International Journal of Learning, Teaching and Educational Research (Vol. 15, Issue 12). https://www.researchgate.net/publication/311457202

Duque, L., Costa, R., Dias, Á., Pereira, L., Santos, J., \& António, N. (2020). New ways of working and the physical environment to improve employee engagement. Sustainability (Switzerland), 12(17). https://doi.org/10.3390/SU12176759

Evans, J. R., \& Mathur, A. (2005). The value of online surveys. Internet Research, 15(2), 195-219. https://doi.org/10.1108/10662240510590360

Ford, R. C., McLaughlin, F. S., \& Newstrom, J. W. (2005). Creating and sustaining fun work environments in hospitality and service organizations. Journal of Human Resources in Hospitality and Tourism, 4(1), 11-30. https://doi.org/10.1300/J171v04n01_02

Goyder, J., \& de Vaus, D. A. (1987). Surveys in social research. Canadian Journal of Sociology / Cahiers Canadiens de Sociologie, 12(4), 422. https://doi.org/10.2307/3340954

Hattingh, S. (2017). Skills planning for the disruptive Fourth Industrial Revolution. HR Future, 2017(Jan 2017), 20-23. https://journals.co.za/content/om_hrf/2017/01/EJC199869

Herzberg, F. (1959). Two-factor Theory of Motivation. In Motivation theory.

Hussain, N., Zehou, S., Anwar UI Haq, M., \& Usman, M. (2014). Conceptualizing employee empowerment through flexible working. European Journal of Business and ManagementOnline), 6(5), 2222-2839.

Jayasinghe, C. (2017). A model of employee well-being for front-line employees in hotel industry. International Journal of Scientific and Research Publications, 7(5), 60. www.ijsrp.org

Judge, T. A., \& Locke, E. A. (1993). Effect of dysfunctional thought processes on subjective well-being and job satisfaction. Journal of Applied Psychology, 78(3), 475-490. https://doi.org/10.1037/0021-9010.78.3.475

Kaihatu, T. S., \& Oktavio, A. (2020). The role of functional top management team in initiating the strategic alliances as outcome from innovativeness behavior: Empirical evidence from star hotels. Jurnal Aplikasi Manajemen, 18(2), 277-288. https://doi.org/10.21776/ub.jam.2020.018.02.08

Kartika, E. W., Nugroho, A., \& Oktavio, A. (2019). How structural and environment variables affect job satisfaction of hotel employees in Surabaya? Binus Business Review, 10(1), 67-74. https://doi.org/10.21512/bbr.v10i1.5593

Kok, M. C., \& Muula, A. S. (2013). Motivation and job satisfaction of health surveillance assistants in Mwanza, Malawi: An explorative study. Malawi Medical Journal, 25(1), 511. https://doi.org/10.4314/MMJ.V25I1

Maroudas, L., Kyriakidou, O., \& Vacharis, A. (2008). Employees' motivation in the luxury hotel industry: The perceived effectiveness of human-resource practices. Managing Leisure, 13(3-4), 258-271. https://doi.org/10.1080/13606710802200969

McCoy, J. M., \& Evans, G. W. (2005). Physical work environment. In Handbook of Work Stress (pp. 219-246). https://doi.org/10.4135/9781412975995.n9

Mitrović, M., Janković, S., \& Ivankovič, G. (2016). Hotel performance measurement: Literature review. SITCON 2016: Quality as a Basis for Tourism Destination Competitiveness, 250-257. https://doi.org/10.15308/sitcon-2016-250-257

Munawirsyah, I. (2017). Pengaruh kepuasan kerja dan fasilitas Kerja Terhadap motivasi Kerja Dan Dampaknya kepada Kinerja Pegawai Non medis Pada Rumah Sakit Umum Daerah Kota Subulussalam. Jurnal Bisnis Administrasi, 06(01), 44-51.

Oktavio, A., \& Kaihatu, T. S. (2020). Implication of future time perspective and hope on the continuance commitment of hotel employees. Jurnal Economia, 16(2), 161-172. https://doi.org/10.21831/economia.v16i2.29711

Oktavio, A., Laurent, M., \& Wijaya, V. (2020). Memprediksi turnover intention melalui 
employee motivation dan employee engagement di Hotel W Bali - Seminyak. Jurnal Konsep Bisnis Dan Manajemen.

Ongori, H. (2009). Managing behind the scenes: A view point on employee empowerment. African Journal of Business Management, 3(1), 009-015. https://doi.org/10.5897/AJBM.9000393

Parveen, S., Sohail, M. M., Naeem, F., Azhar, Z., \& Khan, S. H. (2015). Impact of office facilities and workplace milieu on employees' performance: A case study of Sargodha University. Asian Journal of Empirical Research, 2(4), 96-117.

Rodriguez, J., \& Walters, K. (2017). The importance of training and development in employee performance and evaluation. International Journal Peer Reviewed Journal Refereed Journal Indexed Journal UGC Approved Journal Impact Factor, 3(10), 206212. www.wwjmrd.com

Saif, U., \& Siddiqui, D. A. (2019). Tangible rewards or intangible rewards - Which play most significant role in increasing job-hopping behavior in Generation $Y$ employees in Pakistan? International Journal of Human Resource Studies, 9(4), 275. https://doi.org/10.5296/ijhrs.v9i4.15685

Saunders, M., Lewis, P., \& Thornhill, A. (2016). Research methods for buniess students. In Pearson (7th ed.).

Shabrina, N., \& Chair, I. M. (2020). Pengaruh fasilitas kerja terhadap kepuasan karyawan di Imelda Hotel-Waterpark-Convention Padang. Jurnal Pendidikan Dan Keluarga, 11(02), 117. https://doi.org/10.24036/jpk/vol11-iss02/630

Stavrinoudis, T. A., \& Simos, D. (2016). Factors affecting hotel employees' perception and attitude toward empowerment. Journal of Human Resources in Hospitality and Tourism, 15(4), 416-439. https://doi.org/10.1080/15332845.2016.1148568

Subramanian, K. R. (2018). The connection between your employees and customers. Journal of Advance Research in Business Management and Accounting, 4(8), 1-14. https://www.researchgate.net/publication/327386528_THE_CONNECTION_BETWEEN YOUR_EMPLOYEES AND_CUSTOMERS

Teja, V. Y., \& Oktavio, A. (2019). Pelatihan dan pengembangan karir serta pengaruhnya terhadap peningkatan kinerja karyawan the St. Regis Bali Resort. Jurnal Manajemen Perhotelan, 5(2), 102-108. https://doi.org/10.9744/jmp.5.2.102-108 